\title{
Compressive and Flexural Behaviour of Unstressed Concrete Substructure in Cassava Effluent Contaminated Soils
}

\author{
Adekunle P. Adewuyi ${ }^{*}$, Oluwole A. Olaniyi², Oladipupo S. Olafusi' ${ }^{1}$, Ademola S. Fawumi² \\ ${ }^{1}$ Department of Civil Engineering, Federal University of Agriculture, Abeokuta, Nigeria \\ ${ }^{2}$ Department of Civil Engineering, Ladoke Akintola University of Technology, Ogbomoso, Nigeria \\ Email: ${ }^{*}$ apadewuyi@yahoo.co.uk, ”adewuyiap@funaab.edu.ng
}

Received 12 May 2015; accepted 13 June 2015; published 18 June 2015

Copyright (C) 2015 by authors and Scientific Research Publishing Inc.

This work is licensed under the Creative Commons Attribution International License (CC BY). http://creativecommons.org/licenses/by/4.0/

(c) (i) Open Access

\begin{abstract}
Concrete research is gradually shifting from the conventional strength-based approach to durability-centred in the past decade. Durability is the measure of the robustness of constructed facilities against deterioration tendencies. The rate of deterioration is affected by the loading condition, and more importantly the physical and chemical nature of the host environments. This paper reports the experimental investigation of unstressed concrete substructure in the natural (uncontaminated) and cassava's hydrocyanide effluent-polluted soils on the compressive and flexural strengths of buried concrete specimens for a maximum of 84 days. The compressive strengths of the cubes were tested every 7 days until the 84th day, while the beams were only subjected to third-point loading flexural tests at age 84 days. The compressive strength of concrete specimens in the two soil environments increased, though the trend was lower in the polluted soil. The strength reduced by $2.50 \%$ to $9.47 \%$ between the 7 th and 28 th days, but steadily between the 28 th and 84th days with strength loss of $9.95 \%(\mathrm{COV}=2.64 \%)$. The load-deflection curves were quadratic for the beams in the two geo-environments. The beams in cyanide-polluted soil lost $34.5 \%$ of its flexural stiffness, while its loss of load-carrying capacities at the first crack and ultimate failure was $15.8 \%$ and $20 \%$ respectively. Higher degree of deterioration is certain for loaded concrete substructures in similar conditions. Hence, prior knowledge of soil chemistry is crucial to determining suitable concrete grade and nominal cover for durable substructural elements.
\end{abstract}

\section{Keywords}

Strength Loss, Flexural Stiffness, Soil Contamination, Chemical Attack, Deterioration, Cyanide

\footnotetext{
"Corresponding author.
} 


\section{Introduction}

Durability of concrete in underground structures depends on the chemical properties of the soil and groundwater. Oftentimes, properly designed and constructed concrete infrastructure systems are threatened by deterioration tendencies due to alterations in the internal or host environmental conditions. Consequently, increasing percentages of existing buildings and civil infrastructure have become either structurally deficient or functionally obsolete or both in past one decade as a result of construction defects, aging, material degradation and structural deterioration due to harsh environmental condition (Adewuyi et al. [1] [2], Adewuyi and Wu [3]). Factors such as increase in loading and other usage demand, as well as extreme events including natural disasters may contribute to the failure of civil infrastructure in various degrees, varying from non-optimal performance to a total collapse. Typical environmental conditions that affect concrete durability are temperature, moisture, physical factors, chemical factors and biological factors. These factors may be manifest as deterioration in the form of weathering (temperature and moisture changes), surface erosion, abrasion, cavitations, scaling, spalling, cracking due to crystallization of salts in pores, steel corrosion, strength reduction, delamination, and carbonation (Cohen and Bentur [4], Mehta [5], Kosmatka et al. [6]).

Underground or concrete substructures can sometimes be exposed to sulphates and acids, because water-soluble sulphate exists widely in soil, groundwater, streams, and seawater. It has been recognized for a long time that the sulphate induces damage to concrete (Schneider and Piasta [7]). Consequently, building codes and international standards such as ACI 318 [8], ACI 201 [9], and CSA A23.1 [10]) recommended the cement types, cement contents and water-cement ratios in accordance with the severity of the exposure conditions. DePuy [11] and Marchand et al. [12] revealed the likelihood of potentially destructive conditions on concrete infrastructure even though groundwater or soil chemistry indicates low sulphate content. This phenomenon is particularly critically stressed when concrete is subjected to cycles of wetting and drying. Hong and Hooton [13] examined the effects of cyclic wetting and drying with $\mathrm{NaCl}$ on chloride ingress into concrete. Bentur et al. [14] studied the effect of silica fume in pastes and concretes immersed in 20 and 25\% of magnesium sulphate, magnesium chloride, and sodium sulfate solutions. According to their test results and those of Filho and Agopyan [15], the use of Portland cement with silica fume was highly effective for reducing the deterioration by sodium sulphate solution, but did not seem to be effective for the attack by magnesium sulphate solution. Zuquan et al. [16] investigated the synergistic effects of composite solution of chloride and sulphate on concretes. It was found that sulphate presence reduced chloride diffusion coefficient and concentration by $30 \%-60 \%$ in the short-term, while later increased the ingress of chloride for progressive deterioration.

Bader [17] evaluated chloride diffusion and the deterioration of 4.5-year exposure of concrete specimens to ground conditions of the Arabian Gulf with almost twice the chloride content of Mediterranean or the Atlantic seawaters. The soil condition predominantly high in chloride and sulphate contents enhanced the compressive strength of concrete especially with low water-cement ratio of 0.4 than the corresponding specimens cured in the laboratory. Suphate attack was more intense in concrete specimens with cement contents below and above the optimal $390 \mathrm{~kg} / \mathrm{m}^{3}$. Skalny et al. [18] and Haynes et al. [19] identified swelling, spalling and cracking as the major defects suffered by concrete undergoing sulphate attack. Pradhan and Bhattacharjee [20] evaluated the performance of the performance of different types of rebar in chloride contaminated concrete produced from different cement types. It was found that ordinary Portland cement blended with pozzolans or slag posed greater resistance to chloride-induced steel rebars corrosion in concrete. Mehta [21] and Lea [22] also reported that in addition to ensuring low water-cement ratio, pozzolan and slag blended-cements and/or the use of admixture were so effective means of reducing the sulphate-induced damage. Mehta [21] and Lawrence [23] pointed out that though increasing trichloride-alumina (C3A) content in the cement composition decreased steel corrosion but aggravated the vulnerability to sulphate attack.

The production of cassava (Manihot esculenta crantz) in Nigeria and most tropical countries has progressively transformed from a famine reserve commodity and rural staple food to cash crop that is a major dietary energy source for urban consumption, and as raw materials for industrial purposes both for local and export for international market (Osakwe [24], Ohochuku [25]). Locally, cassava tuber is processed for human and industrial use as traditional flakes (garri), starch or as dried or wet cassava flour. Consequently, establishment of cassava processing milling industries at the nook and crannies of urban and local settlements has come with its corresponding problems of managing the large amount of hydrocyanic acid in the wastewater and solid waste in the form of peels and residue from the pulp. 
Although extensive studies have been conducted on the environmental effects of industrial wastewater on groundwater, aquatic lives and crop production (Aluko et al. [26], Amusan et al. [27], Osemwota [28], Okafor and Uzueqbu [29]) as well as migration of contaminants in groundwater (Ige and Olaifa [30], Olowofela and Akiyemi [31], and Kola-Olusanya [32]), very scanty information is available on the effect of untreated food processing industrial wastes, especially the cassava's cyanide-rich wastewater on the physicochemical and geotechnical properties of engineering soils, and more importantly the effects on the strength and load-carrying capacities of concrete substructures in such contaminated soils. Therefore, this paper reports the comparative study of short-term behaviour of concrete substructures sited in cyanide contaminated soil relative to those in natural unpolluted soils in terms of compressive and flexural strengths and load-carrying capacities.

\section{Materials and Methods}

\subsection{Properties of Cassava Milling Effluent}

Cassava tubers milled and processed at the site are essentially the produce of the Teaching and Research Farm of the University. Hence, they are more likely to be of similar species. The average physical and chemical characteristics of cassava effluents collected in fifteen different days from the milling site are summarized in Table 1.

The $\mathrm{pH}$ value showed that the effluents are acidic much lower than the WHO permissible wastewater effluent of 6.5 - 8.5. The untreated effluent is a potential source of groundwater and soil pollution as the dissolved oxygen content was less than $9.2 \mathrm{ppm}$ (Ademoroti [33]). The cyanide content in the effluent exceeded the $0.07 \mathrm{ppm}$ limit recommended by WHO [34]. Electrical conductivity, being a measure of soil salinity, was very high and indicative of high concentration soluble salts (Latha et al. [35]) and presence of anions in a sizeable quantity. The sulphate content of 158 ppm fell within the moderate category (ACI 318 [8]). Most of the existing codes of practice and international standards only specified the limits for water soluble chloride ion in cement, concrete or seawater; there is hardly a specific limit for exposure to geo-environmental conditions for concrete substructures. The effluent was regarded to be relatively high in hardness, hence there was a palpable fear that it could adversely affect the durability of concrete.

\subsection{Natural and Cassava Effluent Contaminated Soil Conditions}

Two separate pits of $1.5 \times 2.0 \times 1.2 \mathrm{~m}$ deep were excavated within the neighbourhood of the cassava milling and processing site of Teaching and Research Farm of Ladoke Akintola University of Technology, Ogbomosho, Nigeria. The two pits, of similar soil properties, were about 15 meters apart. The physical and chemical properties of the reddish brown clayey sandy soils at depth 1.0 - $1.2 \mathrm{~m}$ depth are summarized in Table 2 and the particle size distribution curve is shown in Figure 1.

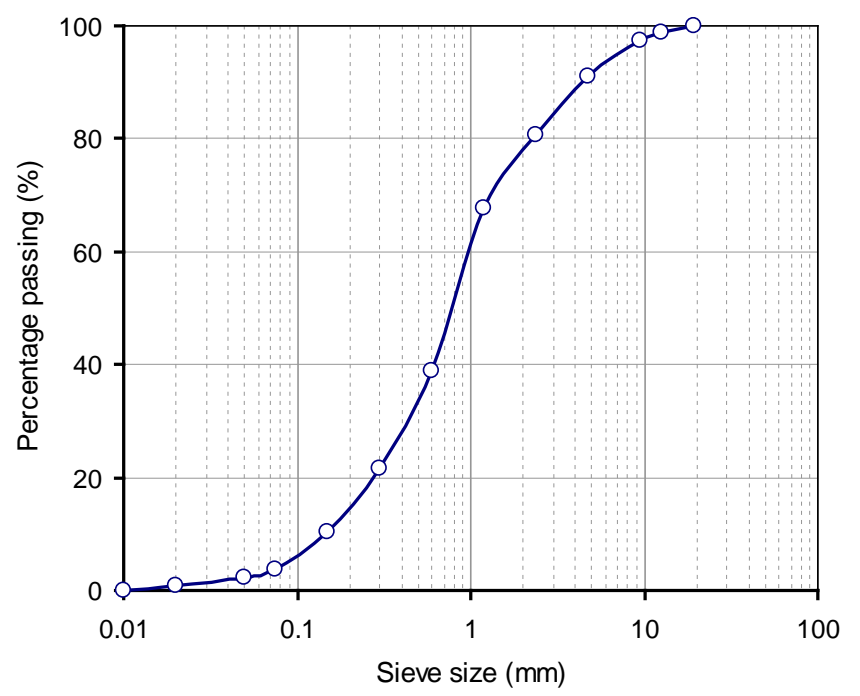

Figure 1. Particle size distribution of soil samples. 
Table 1. Physical and chemical characteristics of effluents from cassava processing mill.

\begin{tabular}{cc}
\hline Parameters & Measurements \\
Colour (Hazen) & 22 \\
$\mathrm{pH}$ & 4.3 \\
Alkalinity $(\mathrm{mg} / \mathrm{l} \mathrm{CaCO}$ ) & 144 \\
Electrical Conductivity $(\mu \mathrm{s} / \mathrm{cm})$ & 50.1 \\
Temperature $\left({ }^{\circ} \mathrm{C}\right)$ & 22.1 \\
Cyanide $(\mathrm{ppm})$ & 0.65 \\
Biochemical oxygen demand, BOD (ppm) & 511 \\
Chemical oxygen demand, COD (ppm) & 193 \\
Dissolved oxygen (ppm) & 4.5 \\
Suspended solids $(\mathrm{ppm})$ & 210 \\
Hardness $(\mathrm{ppm})$ & 600 \\
Sulphate $(\mathrm{ppm})$ & 158 \\
Chloride $(\mathrm{ppm})$ & 160 \\
Nitrate $(\mathrm{ppm})$ & 4.60 \\
\hline
\end{tabular}

Table 2. Physical and chemical properties of unpolluted soil.

\begin{tabular}{cc}
\hline Parameters & Measurements \\
Appearance & Reddish Brown \\
Temperature $\left({ }^{\circ} \mathrm{C}\right)$ & 24.40 \\
$\mathrm{pH}$ & 7.40 \\
Electrical Conductivity $(\mu \mathrm{s} / \mathrm{cm})$ & 65.60 \\
Nitrate $(\mathrm{mg} / \mathrm{kg})$ & 4.60 \\
Phosphate $(\mathrm{mg} / \mathrm{kg})$ & 1.90 \\
Sulphate $(\mathrm{mg} / \mathrm{kg})$ & 18.40 \\
Chloride $(\mathrm{mg} / \mathrm{kg})$ & 20.50 \\
Potassium $(\mathrm{mg} / \mathrm{kg})$ & 13.62 \\
Sodium $(\mathrm{mg} / \mathrm{kg})$ & 11.57 \\
Zinc $(\mathrm{mg} / \mathrm{kg})$ & 0.46 \\
Iron $(\mathrm{mg} / \mathrm{kg})$ & 85.21 \\
Lead $(\mathrm{mg} / \mathrm{kg})$ & 0.88 \\
Manganese $(\mathrm{mg} / \mathrm{kg})$ & 0.38 \\
Chromium $(\mathrm{mg} / \mathrm{kg})$ & 0.04 \\
\hline
\end{tabular}

\section{Experimental Investigation of Concrete Behaviour}

Ordinary Portland cement of grade 42.5 was used. The fine aggregates were river sand and the coarse aggregates were well graded crushed granite of $15 \mathrm{~mm}$ maximum nominal size in conformity with ASTM C33. No addi- 
tives were introduced into the constituents of the concrete. The aggregates were mixed with cement and water at a water-cement ratio of 0.50 in accordance with BS 1881 [36]. The mix proportion of concrete of density is summarized in Table 3.

The 28th and 84th days compressive strength values of $150 \mathrm{~mm}$ concrete cube cured in natural water were 24.25 and $28.18 \mathrm{~N} / \mathrm{mm}^{2}$ respectively. The mean density of fresh concrete was $2459 \mathrm{~kg} / \mathrm{m}^{3}$. The steel reinforcement ratio of 0.35 percent of the concrete area was adopted for all the beams corresponding to $4 \Phi 10 \mathrm{~mm}$ bars (two bars each at the tension and compression zones). The stirrups were $10 \Phi 8 \mathrm{~mm}$ steel bars spaced at $100 \mathrm{~mm}$ centres and the nominal cover was $25 \mathrm{~mm}$. The bottom of the excavated pit was level so that the specimens were placed horizontally. Thirty-six $150 \mathrm{~mm}$ concrete cube and six $150 \times 150 \times 900 \mathrm{~mm}$ concrete beam specimens were placed in each of the pits in the natural and cassava-effluent polluted areas $24 \pm 2$ hours after casting. Prior to filling the pits with earth materials, the concrete specimens in the natural site were filled to level with pure uncontaminated water, while those in the simulated contaminated area were filled with the composite of cassava effluent mixed with pure water in equal proportions to the level of the topmost specimens. The fifty-percent dilution was considered for the contaminated zone because it was assumed that the concentration distribution decreases downward through the soil layers. The excavated pits for the two geo-environmental conditions are shown in Figure 2.

In order to ensure sufficient hydration of the buried concrete specimens in the first 28 days, adequate natural water was poured on the ground surface of the control experiment, while undiluted cassava effluent was discharged onto the contaminated site to keep the buried specimens sufficiently soaked with saturated soils. Three cubes were taken out for compressive strength tests every 7 days until the 84th day, while the RC beams were only tested for flexure at the 84th day. However, the 28th day flexural test was not conducted as no physical difference was observed in the beams specimens in the two pits. Three additional concrete cubes were cured in water by full immersion to determine the 28th day compressive strength.

The laboratory setup for compressive and flexural strength tests are shown in Figure 3, while Figure 4 illustrates the geometric and reinforcement details of the RC beams for flexural tests. The central concentrated load on the RC beams was applied with the aid of a hydraulic jack and calibrated dial gauges were sited directly on the underside of the concentrated loads at the middle thirds to measure the deflections under the applied loads. The measured deflections at the two locations were comparable and the applied load was plotted against the mean deflection for the beams buried in the natural (uncontaminated) and cassava effluent-polluted soils.

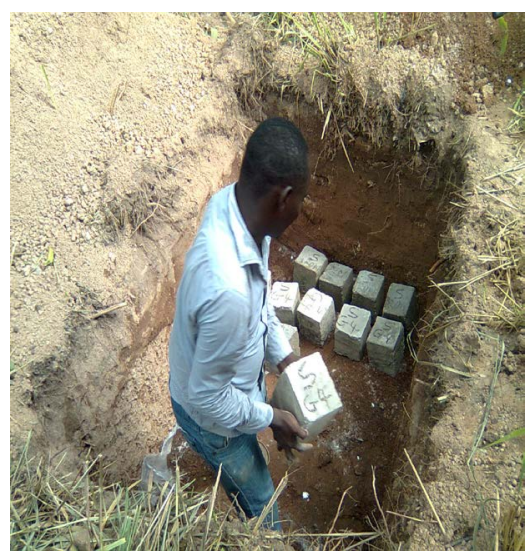

(a)

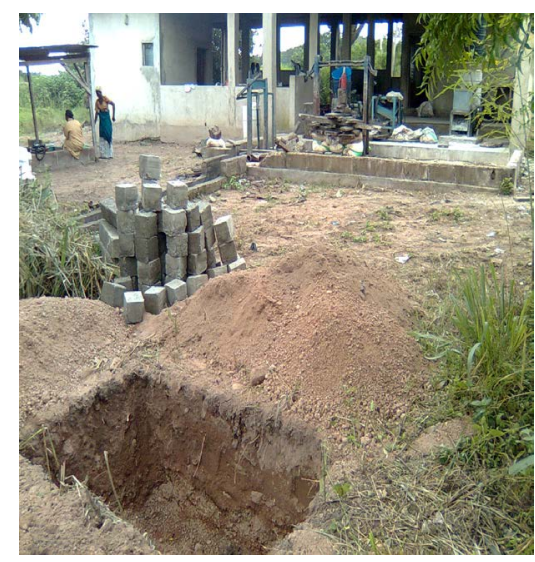

(b)

Figure 2. Excavated pits (a) natural unpolluted soil and (b) cyanide contaminated soil near cassava milling and processing site.

Table 3. Mix proportioning of constituents of concrete.

\begin{tabular}{ccccc}
\hline & Water & Cement & Fine aggregates & Coarse aggregates \\
\hline Mass (kg) & 159 & 318 & 661 & 1321 \\
Ratio & 0.50 & 1.00 & 2.08 & 4.15 \\
\hline
\end{tabular}




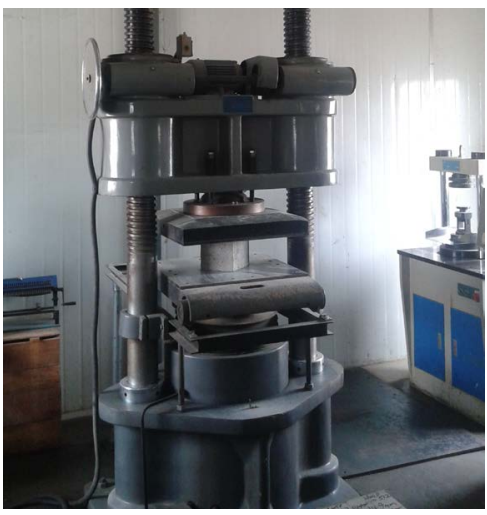

(a)

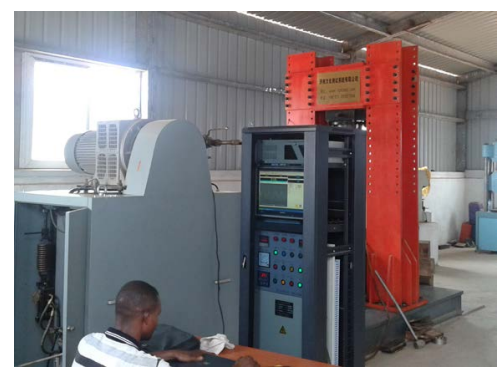

(b)

Figure 3. Laboratory setup for (a) compressive and (b) flexural strength tests.

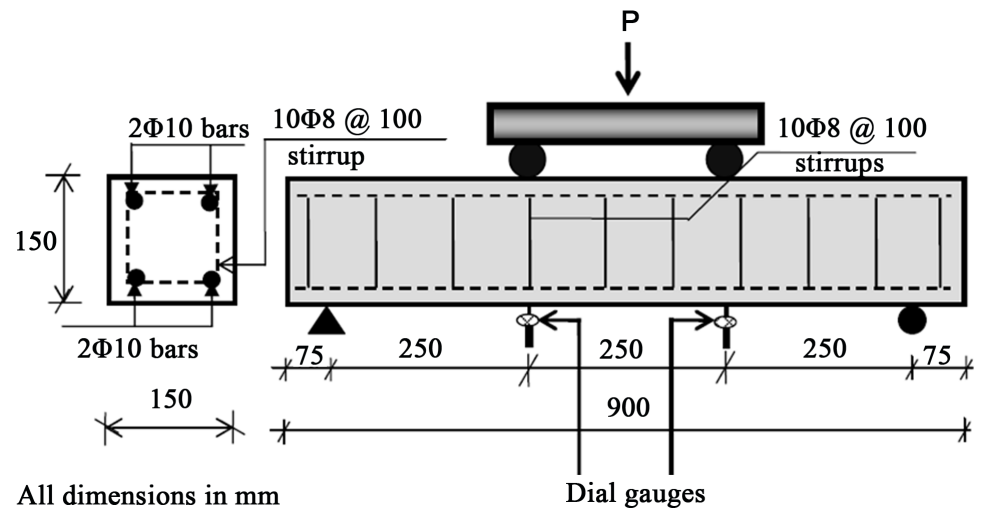

Figure 4. Third-point loading flexural test setup for beams.

\section{Results and Discussion}

\subsection{Physical Appearance of Concrete Specimens}

At the end of the exposure period, no visible cracks were noticed up to the 35th day of the experiment. However, surface scaling which was made of a whitish powdery substance suspected to be crystallized sulphate compounds and cyanide was observed on the surface of cubes buried in the effluent contaminated soils on the 42nd day. Also, because the colour of the effluent exceeded the 5 Hazen limit for industrial wastewater (WHO [34]), there was the likelihood of the presence of dissolved substances which could catalyze degradation of concrete. Greenish substances were forming on the surface of the concrete specimen at age 63 days; this growth was suspected to have been enhanced due to high BOD of the effluent. Surprisingly, there was no marked mass change in the concrete cubes when compared with the control specimens in the unpolluted geoenvironmental condition. Hence, mass loss is presumed an unreliable damage index.

\subsection{Compressive Strength of Concrete}

The compressive strength test results for the twelve test days from age 7 to 84 days are plotted in Figure 5. The compressive strength of concretes in the two geo-environments exhibited similar pattern in that the strength increased curvilinearly at a decreasing rate. However, the strength of concrete specimens in the effluent-contaminated soil was lower in strength. The mean 28th day compressive strength of similar concrete specimen cured in water tank was $24.25 \mathrm{~N} / \mathrm{mm}^{2}$, one interesting observation is that regardless of how natural and contaminationfree the soil condition might be, the compressive strength of concrete cured in geoenvironmental conditions is less the water-cured concrete strength. For example, 28th day compressive strength in the natural and cassavaeffluent contaminated soil reduced by $12.0 \%$ and $20.4 \%$ respectively compared to the water-cured strength. 


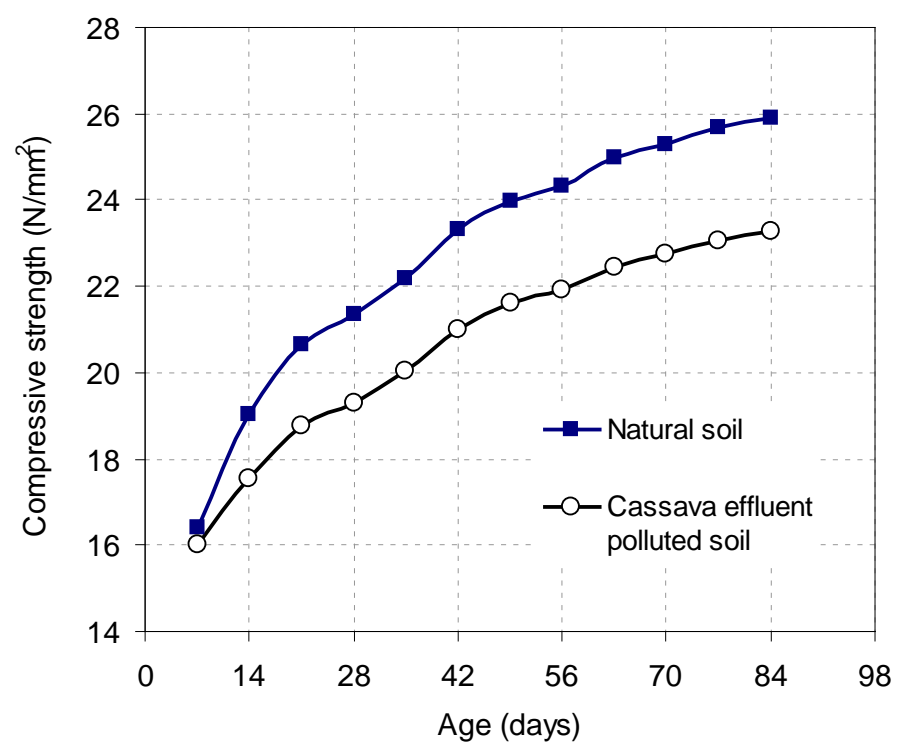

Figure 5. Compressive strength of concrete cube buried in natural and effluent polluted soils at varying crushing ages.

From compressive strength of the concrete specimens in the two soil conditions, the strength loss to the contaminants in the cassava-effluent soaked soil is extracted with respect to the ages and presented in Figure 6. The percentage strength loss, calculated as the difference between the compressive strength of concrete specimens in the two soil conditions at any test day divided by the compressive strength value in the uncontaminated soil, increased sharply from $2.5 \%$ at age 7 days to $9.47 \%$ at 28 days, but became steady beyond age 28 days when the concrete specimens were believed to have attained over 70 percent hydration (Kosmatka et al. [6]). The strength loss between 28 and 84 days was 9.95\% (COV = 2.64\%).

Although Zuquan et al. [16] submitted that composite action of sulphate in chloride environment slows down the chloride diffusion on the short-term, while chloride ingress was aggravated for progressive deterioration after a couple of months of concrete exposures to such harsh operational conditions. The chloride, sulphate, nitrate and particularly cyanide contents of the contaminated soil attacked concrete constituents, which was evident in the dramatic loss of compressive strength of concrete. The presence of heavy metals in the soil is another factor that affected the compressive strength of the concrete cubes over a period of time. Since the concrete cubes were buried and sufficiently left soaked too allow the biochemical constituents of the soil to react with concrete. Beyond 28 days, the time-dependent prediction model of compressive strength loss, $S_{l}$, was perfectly logarithmic $\left(R^{2}=0.94\right)$ and can be expressed mathematically as:

$$
S_{l}=0.685 \ln t+7.232
$$

where $t$ (in days) is the age of concrete in the cassava-effluent geo-environmental conditions.

The 40-year predictive model of deterioration pattern of concrete in cassava effluent contaminated soil in terms of the compressive strength loss is presented in Figure 7.

\subsection{Flexural Behaviour of RC Beams in Cassava Effluent Contaminated Geoenvironment}

Out of the six $150 \times 150 \times 900 \mathrm{~mm}$ RC beams buried in each of the two pits, only three were tested for pure flexural load under third-point loading at 84 days. The mean load-deflection $(\mathrm{P}-\delta$ ) curves of three replicas are shown in Figure 8. The P- $\delta$ curves of the beams in the two environments are perfectly quadratic. The flexural behaviours of the beams were examined in terms of the stiffness, loss of load-carrying capacities at first crack and ultimate load. Although the specimens in the two soil environments had second stiffness after the first crack occurrence, the biochemical attacks increased the ductility and thereby reduced the load-carrying capacity of the $\mathrm{RC}$ beams in the effluent contaminated soil.

The stiffness of the RC beams in the natural and contaminated soils prior to the first crack were 71.57 and $46.86 \mathrm{kN} / \mathrm{mm}$ respectively. It is evident from this results that $34.5 \%$ of the first flexural stiffness was lost to the 


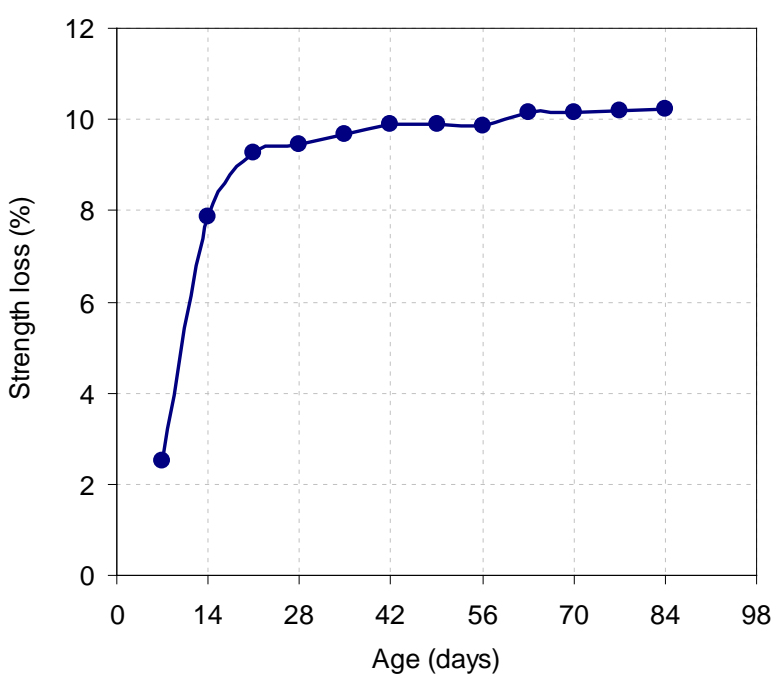

Figure 6. Percentage strength loss of concrete due to cassava effluent contaminated soil.

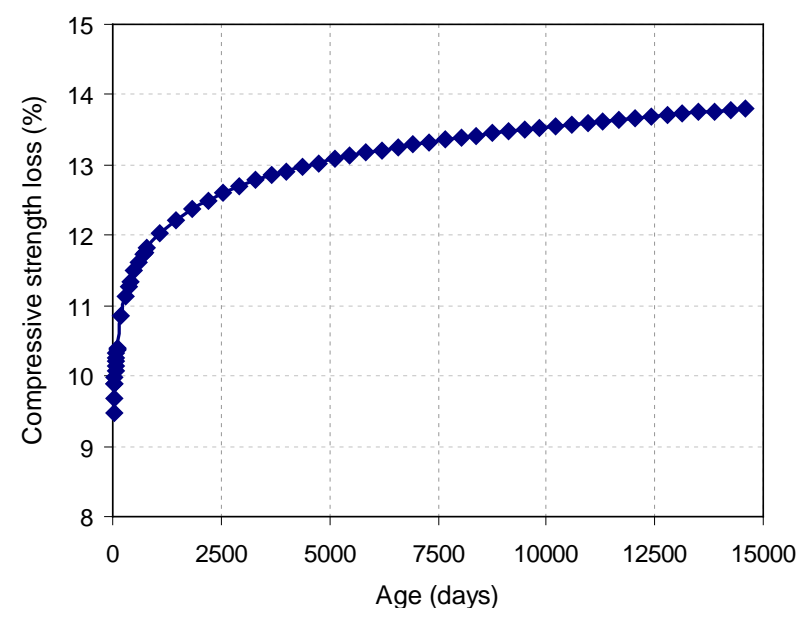

Figure 7. Logarithmic predictive model for long-term compressive strength loss to cassava effluent contaminated soil.

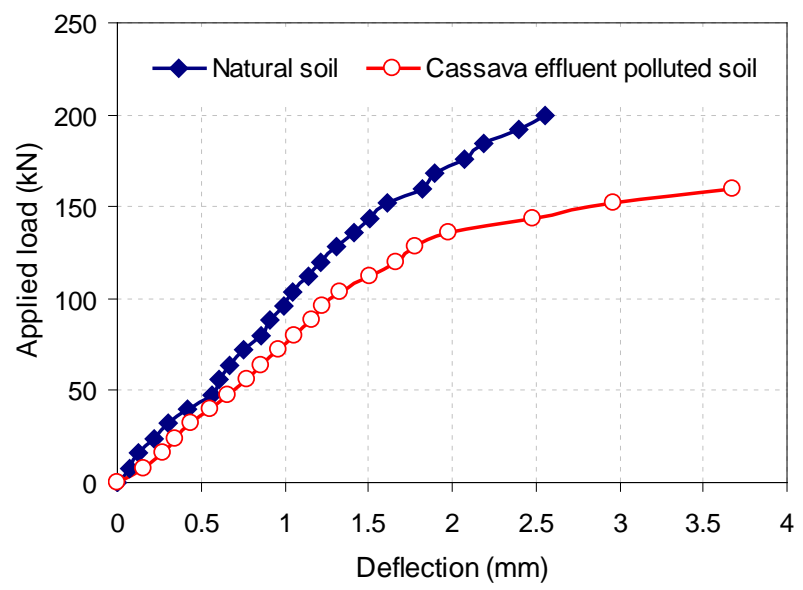

Figure 8. Load-deflection curve of RC beams buried in natural and cassava effluent polluted soils. 
harsh geoenvironmental attack on the beams. In addition, the first cracking and ultimate loads of RC beams in the natural soil condition were 152 and $200 \mathrm{kN}$, while the beams in the contaminated soil lost $15.8 \%$ and 20.0\% of the load-carrying capacity at first crack and ultimate collapse respectively to the environmental attacks on the beams due to indiscriminate discharge of cassava milling wastewater Furthermore, it is quite interesting to note that the first crack to ultimate load ratio are essential structural performance index. The load ratio of the RC beams in the natural and contaminated soils were $76 \%$ and $80 \%$-implying that the former had $24 \%$ residual loadcarrying capacity after the first crack. Concrete beams attacked by cassava effluent had $20 \%$ of its capacity left after the first crack.

In conclusion, for concrete elements exposed to such environmental attacks as cassava effluent in unstressed state to have recorded such alarming deterioration effect in form of material degradation and loss of structural integrity and load-carrying capacities in compression and tension, existing constructed facilities under similar conditions would definitely be disastrous. It is, however, indisputable that concrete of grade $25 \mathrm{~N} / \mathrm{mm}^{2}$ is not suitable for foundation elements in cassava effluent-contaminated geoenvironmental conditions. Hence, prior knowledge of soil chemistry is crucial to determining suitable concrete grade and nominal cover for durable substructural elements.

\section{Conclusions}

The experimental investigation presented in this paper indicates that exposure of concrete structures to attacks from cassava effluent-contaminated soil certainly results in significant reorganization of the internal microstructure of concrete elements. The effects of such exposure on concrete are summarized as follows:

1) The strength loss of concrete in compression could be as high as $9.47 \%$ in short-term and about $14 \%$ in long-term.

2) The losses of flexural stiffness and load-carrying capacities at first crack and ultimate load were $34.5 \%, 15.8 \%$ and $20 \%$ respectively.

3) The residual load-carrying capacity of concrete flexural member was $20 \%$ after the first crack.

4) It is evident that concrete of grade $25 \mathrm{~N} / \mathrm{mm}^{2}$ is not suitable for foundation elements in cassava effluentcontaminated geoenvironmental conditions.

5) Preliminary investigation for geotechnical properties of the soil is inadequate. Comprehensive soil analysis to evaluate soil chemistry should be encouraged.

\section{References}

[1] Adewuyi, A.P., Wu, Z.S. and Serker, N.H.M.K. (2009) Assessment of Vibration Based Damage Identification Methods Using Displacement and Distributed Strain Measurements. International Journal of Structural Health Monitoring, 8, 443-461. http://dx.doi.org/10.1177/1475921709340964

[2] Adewuyi, A.P., Wu, Z.S. and Raheem, A.A. (2010) Adaptation of Vibration-Based SHM for Condition Assessment and Damage Detection of Civil Infrastructure Systems. LAUTECH Journal of Engineering \& Technology, 6, 1-11.

[3] Adewuyi, A.P. and Wu, Z.S. (2011) Vibration-Based Damage Localization in Flexural Structures Using Normalized Modal Macrostrain Techniques from Limited Measurements. Computer-Aided Civil and Infrastructure Engineering, 26, 154-172. http://dx.doi.org/10.1111/j.1467-8667.2010.00682.x

[4] Cohen M.D. and Bentur A. (1988) Durability of Portland Cement-Silica Fume Pastes in Magnesium Sulfate and Sodium Sulfate Solutions. ACI Materials Journal, 85, 148-157.

[5] Mehta P.K. (1983) Mechanism of Sulfate Attack on Portland Cement Concrete: Another Look. Cement \& Concrete Research, 13, 401-406. http://dx.doi.org/10.1016/0008-8846(83)90040-6

[6] Kosmatka, S.H., Kerkhoff, B. and Panarese, W.C. (2003) Design and Control of Concrete Mixtures. 14th Edition. Portland Cement Association, Skokie.

[7] Schneider, U. and Piasta, W.G. (1991) The Behaviour of Concrete under $\mathrm{Na}_{2} \mathrm{SO}_{4}$ Solution Attack and Sustained Compression or Bending. Magazine for Concrete Research, 43, 281-289. http://dx.doi.org/10.1680/macr.1991.43.157.281

[8] American Concrete Institute (2008) Building Code Requirements for Structural Concrete, ACI 318-08. Farmington Hills.

[9] American Concrete Institute (1999) Guide to Durable Concrete. ACI 201.2R-99. Farmington Hills.

[10] Canadian Standard Association (1994) Concrete: Constituents and Construction Practices, A23.1-94. Rexdale, Ontario.

[11] DePuy, G.W. (1994) Chemical Resistance of Concrete. In: Klieger, P. and Lamond, J.., Eds., Significance of Tests and 
Properties of Concrete and Concrete-Making Materials, STP 169C, ASTM, Philadelphia, 263-281.

[12] Marchand, J., Samson, E., Maltais, Y. and Beaudoin, J.J. (2002) Theoretical Analysis of the Effect of Weak Sodium Sulfate Solutions on the Durability of Concrete. Cement \& Concrete Composites, 24, 317-329. http://dx.doi.org/10.1016/S0958-9465(01)00083-X

[13] Hong, K. and Hooton, R.D. (1999) Effects of Cyclic Chloride Exposure on Penetration of Concrete Cover. Cement \& Concrete Research, 29, 1379-1386. http://dx.doi.org/10.1016/S0008-8846(99)00073-3

[14] Bentur, A., Goldman, A. and Ben-Bassat, M. (1995) High Performance Concretes in Concentrated Magnesium Sulfates, Magnesium Chlorides and Sodium Sulfates Solution. Proceedings of the International Conference on Concrete under Severe Conditions: Environment and Loading, Sapporo, 2-4 August 1995, 1237-1246.

[15] Filho, L.C.P.S. and Agopyan, V. (1995) Effect of Silica Fume on Concretes against Sulfate Attack. Proceedings of the International Conference on Concrete under Severe Conditions: Environment and Loading, Sapporo, 2-4 August 1995, 1227-1236.

[16] Zuquan, J., Wei, S., Yunsheng, Z., Jinyang, J. and Jianzhong, L. (2007) Interaction between Sulfate and Chloride Solution Attack of Concretes with and without Fly Ash. Cement and Concrete Research, 37, 1223-1232. http://dx.doi.org/10.1016/j.cemconres.2007.02.016

[17] Bader, M.A. (2003) Performance of Concrete in Coastal Environment. Cement \& Concrete Composites, 25, 539-548. http://dx.doi.org/10.1016/S0958-9465(02)00093-8

[18] Skalny, J., Marchand, J. and Odler, I. (2001) Sulfate Attack on Concrete. E \& FN, London.

[19] Haynes, H., O’Neill, R. and Mehta, P.K. (1996) Concrete Deterioration from Physical Attack by Salt. Concrete International, 18, 63-68.

[20] Pradhan, B. and Bhattacharjee, B. (2009) Performance Evaluation of Rebar in Chloride Contaminated Concrete by Corrosion Rate. Construction and Building Materials, 23, 2346-2356. http://dx.doi.org/10.1016/j.conbuildmat.2008.11.003

[21] Mehta, P.K. (1990) Concrete in the Marine Environment (Modern Concrete Technology). CRC Press, Boca Raton.

[22] Lea, F.M. (2003) The Chemistry of Cement and Concrete. Chemical Publishing Co., New York, 89-114.

[23] Lawrence, C.D. (1990) Sulphate Attack on Concrete. Magazine of Concrete Research, 42, 249-264. http://dx.doi.org/10.1680/macr.1990.42.153.249

[24] Osakwe, S.A. (2012) Effect of Cassava Processing Mill Effluent on Physical and Chemical Properties of Soils in Abraka and Environs, Delta State, Nigeria. Chemistry and Materials Research, 2, 27-39.

[25] Ohochuku, N.S. (2005) Odorless Fermentation of Tubers of Cassava (Manchot esculenta Graritz). Journal of Health and Environmental Research, 6, 62-69.

[26] Aluko, O.O., Sridhar, M.K.C. and Oluwande, P.A. (2003) Characterization of Leachates from a Municipal Solid Waste Land Fill Site in Ibadan, Nigeria. Journal of Environmental Health Research, 2, 32-37.

[27] Amusan, A.A., Ige, D.V. and Olawale, R. (2005) Characteristics of Soils and Crops Uptake of Metals in Municipal Waste Dumpsites in Nigeria. Journal of Human Ecology, 17, 167-171.

[28] Osemwota, O.I. (2010) Effect of Abattoir Effluent on the Physical and Chemical Properties of Soils. Environmental Monitoring Assessment, 167, 399-404. http://dx.doi.org/10.1007/s10661-009-1058-7

[29] Okafor, N. and Uzuegbu, J.O. (1987) Studies on the Contribution of Micro-Organism on the Organo-Leptic Properties of Garri-A Fermented Food Derived from Cassava (Manilot esculenta Crantz). Journal of Food and Agriculture, 2, 99-105.

[30] Ige, O.O. and Olaifa, A.O. (2013) Groundwater Pollution Assessment around Waste Disposal Sites in Part of Lagos State, Nigeria. ARPN Journal of Earth Sciences, 2, 54-61.

[31] Olowofela, J.A. and Akinyemi, O.D. (2001) A Numerical Model for the Migration and Fate of Contaminants in Groundwater. Nigerian Journal of Science, 35, 87-93.

[32] Kola-Olusanya, A. (2012) Impact of Municipal Solid Wastes on Underground Water Sources in Nigeria. European Scientific Journal, 8, 1-19.

[33] Ademoroti, C.M.A. (1996) Environmental Chemistry and Toxicology. Foludex Press Ltd., Ibadan.

[34] World Health Organization (2004) Maximum Allowable Concentration of Selected Water Quality Variables. WHO, Geneva.

[35] Latha, P., Thangavel, P., Velayutham, K. and Arulmozhiselvan, K. (2012) Effect of Distillery Industrial Wastes Application on Nutrient Dynamics in Soil. International Journal of Advanced Life Sciences, 4, 16-23.

[36] BS 1881 (2013) Testing Concrete. Methods for Mixing and Sampling Fresh Concrete in the Laboratory, Part 125. British Standards Institution, London. 